\title{
The effect of fiber diet on colonic cancer formation: the role of butyrate
}

\author{
Ari Fahrial Syam
}

\begin{abstract}
Abstrak
Kejadian kanker kolon mayoritas terjadi secara sporadik. Berbagai faktor non-inherited yang dipikirkan sebagai penyebab kanker kolon merupakan kombinasi antara faktor diet dan lingkungan. Kedua faktor ini menyebabkan mutasi somatik pada berbagai gen spesifik dalam pembentukan kanker kolon. Di antara berbagai faktor, butirat (dibentuk dalam proses fermentasi fiber) mungkin mempunyai peranan yang penting sebagai zat kemoprotektif terhadap kanker kolon. Sumber butirat dalam makanan sehari-hari berasal dari makanan yang mengandung kulit gandum. Pada tingkat molekuler, butirat menyebabkan asetilasi histon, meningkatkan diferensiasi berbagai sel, menginduksi terjadinya apoptosis dan meregulasi ekspresi dari berbagai onkogen. Faktor-faktor ini yang menjadi alasan butirat mempunyai efek protektif terhadap kanker kolon. (Med J Indones 2003; 12: 127-31)
\end{abstract}

\begin{abstract}
The majority of colon cancers occur sporadically. They are thougth to be caused by non-inherited factors such as a combination of diet and environmental factors, which result in somatic mutations of specific genes. Among dietary factors butyrate which is derived from fermentable fibers may have important role as chemoprotector against colorectal cancer. The source of butyrate in daily diet mostly come from wheat products especially wheat bran. At molecular level, butyrate causes hystone acetylation, favours differentiation, induces apoptosis and regulates the expressions of various oncogens. These effects suggest that butyrate may be protective against colorectal cancers. (Med J Indones 2003; 12: 127-31)
\end{abstract}

Keywords: colon cancer, dietary fiber, apoptosis

Colon cancer is a major cause of cancer related deaths in the industrialized world and mortality figures have not improved in the last few decades. The majority of colon cancer occurs sporadically. There is strong epidemiological evidence for the involvement of dietary factors. ${ }^{1}$ Colon cancers are thought to be caused by non-inherited factors such as combination of diet and environment, which result in somatic mutation of specific genes such as RB1, p16, ras or $\mathrm{p} 53 .{ }^{2}$

The two dietary components that have effect on colonic cytokinetics and tumor development are dietary fat and fiber. There are considerable data to support the concept that the type of fat or fiber is actually more important to tumor development than is the amount of either of these components in the diet. ${ }^{3,4}$

Division of Gastroenterology, Department of Internal Medicine, Faculty of Medicine University of Indonesia / Dr. Cipto

Mangunkusumo Hospital, Jakarta, Indonesia
Among dietary factors, butyrate (derived from fermentable fiber) may be utilized as a chemopreventive agent for colon cancers. This short-chain fatty acid is a product of fiber fermentation by resident anaerobic bacteria in the normal colon. It is particularly important for several reasons: first, butyrate is the primary fuel source of colonocytes, it is utilized preferentially over glucose, glutamine and other short-chain fatty acids; second, butyrate has been shown to increase celluler proliferation in normal colonocytes, ${ }^{5}$ and finally, butyrate has been shown in cell culture system to increase markers of differentiation and induce apoptosis. ${ }^{6}$ However, the specific mechanism by which butyrate induces apoptosis have not been fully elucidated. ${ }^{7}$ Nevertheless, data from several laboratories have suggested a potential scenario for butyrate-induced apoptosis. $^{8,9}$ This review presents informations about the balance between proliferation, differentiation and apoptosis in colonic epithelium, the role of apoptosis in colon cancer, and the possible mechanism by which butyrate induces apoptosis. 


\section{PROLIFERATION, DIFFERENTIATION AND APOPTOSIS IN COLONIC EPITHELIUM}

One of the outstanding questions in cancer research is how the genetic changes that occur during carcinogenesis alter the balance between proliferation, differentiation and cell death, as all three characteristics can be directly measured in vitro. An increase in the population of cells can occur by increased mitosis/ proliferation rate or by a decreased cell death rate.

In the colonic crypt, cell proliferation is confined to the lower two thirds of the crypt. As cells migrate up the crypt, the cells differentiate into absorptive enterocytes, mucous secreting goblet cells or enteroendocrine cells. There is continuos movement of cells up the crypts and this is tightly coupled to differentiation. The fate of the cells once they reach the top of the crypt is a matter of some controversy, as the process is poorly understood. Exfoliation could be due to a programmed cell death mechanism (apoptosis). As disruption of cell-to-cell contact occurs during apoptosis, loss of the cells at the top of the crypt could be a direct consequence of apoptosis rather than passive or mechanical mechanisms. ${ }^{10}$

Total crypt cell number and phenotype are strictly maintained by a balance between cell proliferation, differentiation and apoptosis. Dysregulation of the balance has a significant consequence for colonic crypt homeostasis, leading to the development of adenomas and eventually cancer. ${ }^{11}$

\section{THE ROLE OF APOPTOSIS IN COLON CANCER}

Colorectal cancer develops as a result of the pathologic transformation of normal colonic epithelium to an adenomatous polyp and in the end to an invasive cancer. The multistep progression requires years and possibly decades and is accompanied by a number of recently characterized genetic alterations. There is a number of genes which are mutated during colorectal carcinogenesis. Mutations in two classes of genes, tumor suppresor genes and proto-oncogenes, are thought to give a proliferative advantage to cells and contribute to the development of the malignant phenotype.

Programmed cell death (apoptosis) is a physiological process that plays an essential role in normal tissue turnover and embryonic development. It is a dominant manner in which cells die in vivo. Its primary function is to balance cell proliferation, removing redundant cells in a manner, which does not induce an inflammatory reaction or potential harm to the host. ${ }^{12}$ Three morphological stages have been identified in cells undergoing apoptosis; in the initial stage, the cells shrink in size, cellular chromatin condenses and organelles begin to aggregate. The second stage is characterized by membrane blebbing, where small portions of plasma membrane form vesicles containing various cellular components, which bud off from the main body of the cell. In the final stage, nuclear material and cellular structures within these apoptotic bodies undergo degeneration. It is important to note that apoptosis is quite distinct from necrosis, as necrosis releases cellular contents and induces inflammation. ${ }^{12}$

Apoptosis is characterized by the need for new gene expression. Several genes that control the regulation of apoptosis have been identified, such as Bcl-2, p53 and cmyc. The p53 gene affects cell cycle progression; the resulting expression of p53 protein causes cell cycle arrest at $G_{1}$ stage, allowing time for damaged DNA to repair itself when the damage is repairable. ${ }^{13}$ The p53 gene is located on the short arm of chromosome 17, which is deleted in $75 \%$ of colorectal cancers. ${ }^{14} \mathrm{~A}$ study showed that Bcl-2 null mice exhibited increased loss of small intestinal cells by exfoliation and a significant reduction in mitotic progenitor cells, indicative of an important functional role for Bcl-2 in the regulation of cellular turnover in the intestine. ${ }^{15}$

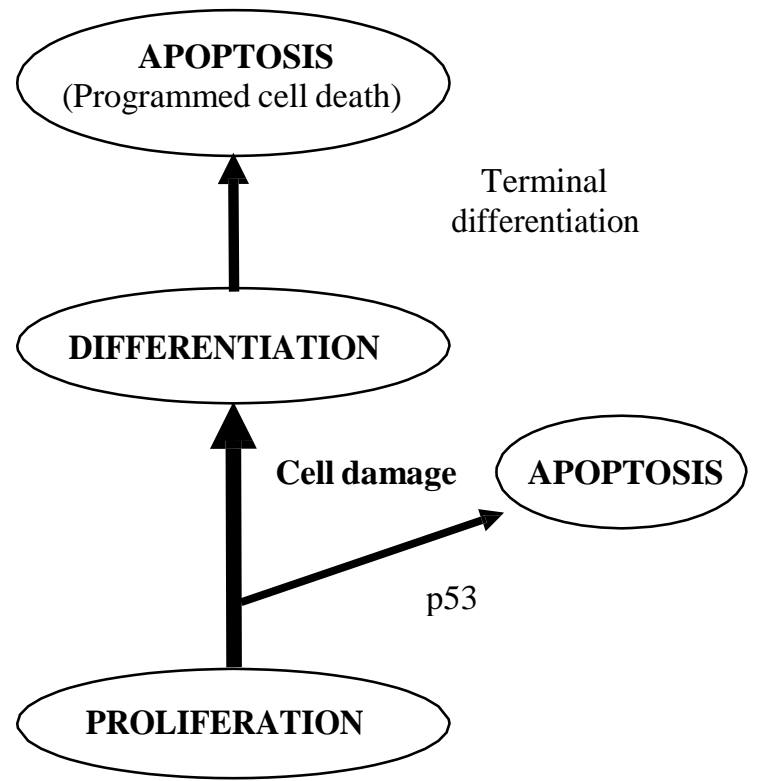

Figure 1. Tissue homestasis in the normal colonic crypt relies on a balance between proliferation, differentiation and apoptosis. Rapid apoptosis occur in the proliferation zone as a response to cell damage and is largely $p-53$ dependent (Merrit, 1994) 


\section{BUTYRATE INDUCES APOPTOSIS}

Butyrate, a short chain (four-carbon) fatty acid is a fermentation product of dietary fiber such as wheat bran by resident anaerobic bacteria in the normal colon. Some studies showed that wheat bran produced significantly higher fecal butyrate levels (6-10 times more) than fiber-free diet. ${ }^{8,16,17}$ Charles et al found that $20 \%$ wheat bran diet delivered a higher butyrate level in colon than fiber free diet. ${ }^{17}$

Previous studies examining the protective effect of dietary fiber on colonic neoplasia have pointed to butyrate as the key mediator of these effects (see figure 2). ${ }^{18}$

Butyrate is a natural component of colonic milieu and has been shown to inhibit the growth of colonic carcinoma cells, both in vivo and in vitro. A study showed that butyrate prevented and decreased growth of chemically induced colonic cancer in rat. In vitro, butyrate has been shown to inhibit growth of colonic carcinoma cells such as HT-29 and LM $1215 .{ }^{19}$ Another study found that butyrate could arrest colon cancer cells in $\mathrm{G}_{1}{ }^{20}$

In vivo studies using rat models with large bowel cancer indicated that high-fiber diets that are associated with high butyrate levels prevented or decreased the incidence of colon cancers. In vitro studies, butyrate has been shown to slow the proliferation and promote the expression of phenotypic markers of differentiation in colon cancer cell lines. In addition, butyrate had also been shown to have another effects on cells in vitro and on tumor cells, i.e. inducing apoptosis. ${ }^{6}$

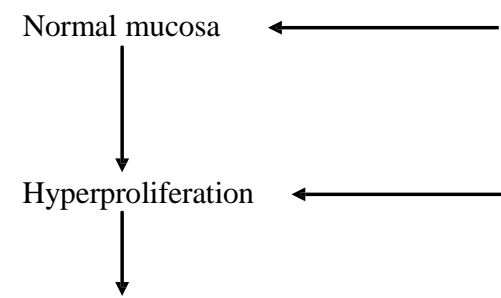

Early adenoma

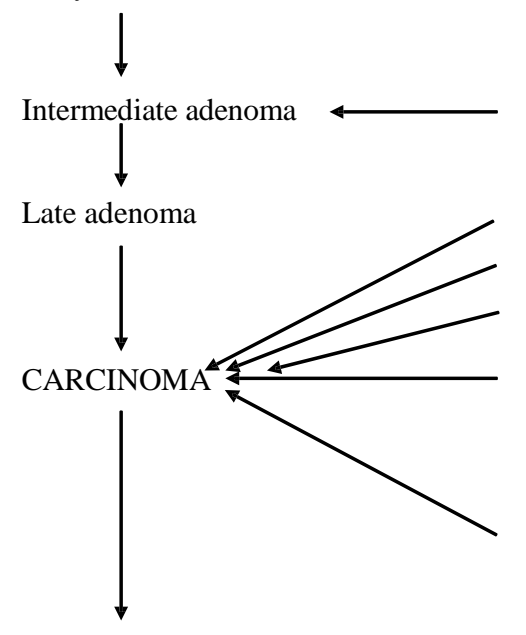

Metastases
Stimulation of proliferation in the basal crypt

Inhibition of proliferation in the upper crypt acetate, butyrate, propionate

butyrate

Induction of apoptosis

Inhibition of proliferation Stimulation of differentiation Hyperacetylation of histones

Alterations in gene expression

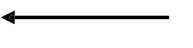
butyrate, propionate butyrate butyrate butyrate

Effects on extracellular matrix butyrate

Regression of carcinomatosis in vivo interleukin-2\&butyrate

Figure 2. Effects of short-chain fatty acids (SCFA) on colonic epithelial cells at different stages of the adenoma-carcinoma sequence (Scheppach et al 1995) $^{18}$ 
The specific mechanisms by which butyrate induces apoptosis are not known. Nevertheless data from several studies have suggested a potential scenario for butyrate-induced apoptosis. Apoptosis induction by butyrate is a novel pathway, including activating caspase- 3 and requiring new protein synthesis but independent of $\mathrm{p} 53 .^{21}$ The p53 promotes apoptosis and $\mathrm{G}_{1}$ arrest to allow the cell enough time to undergo DNA repair prior to cell division. In addition, butyrate is known to induce a variety of changes within nucleus, including histone hyperacetyltion due to inhibition of histone deacetylase, and DNA methilation. Histone hyperacetylation generally has been associated with both a decrease in cell growth and the activation of specific gene.

Butyrate is present in colon together with unconjugated bile acids. The unconjugated bile acids including chenodeoxycholic acid (CDCA) and deoxycholic acid (DCA) have been shown to be tumor promoting factors in animal studies ${ }^{22}$ and raised levels of secondary bile acids have been reported in patients with adenomatous polyps and colon cancer. $^{23}$ However, until now, their mechanism of action is poorly understood.

McMillan et al showed that bile acids were able to inhibit the apoptosis-inducing effects of the short chain fatty acid, butyrate. Bile acids significantly inhibited the induction of apoptosis by butyrate in AA/C1 cells, but the survival-inducing effects of bile acids on AA/C1 cells could be overcome by increasing the concentration of sodium butyrate in AA/C1 cells. ${ }^{24}$ From these studies, we can see the beneficial effects of butyrate regarding the protection against colon cancer, due to its ability to induce apoptosis in colon cells per se, and to the inhibition of the survival effects provided by secondary bile acids.

In conclusion, the balance between cell growth, differentiation and cell death maintains tissue homeostasis in the colonic crypt. Deregulation of these processes plays an important role in the colonic carcinogenesis. Butyrate a four carbon fatty acid produced by fermentation of fiber can promote differentiation and apoptosis in a variety of colon tumor cell lines. However, the molecular mechanisms by which butyrate mediates its effects are not well understood. Studies in these areas are of potential clinical interest, because agents that promote differentiation and apoptosis in colon cancer cells may be used in the strategies directed toward the prevention and treatment of colon cancer.

\section{REFERENCE}

1. Williams AC, Hague A, Elder DJ, Paraskeva C. In vitro models for studying colorectal carcinogenesis: cellular and molecular events including APC and Rb cleavage in the control of proliferation, differentiation and apoptosis. Biochim Biophys Acta 1996; 1288:F9-19.

2. Fearon ER. Human cancer syndrome: clues to the origin and nature of cancer. Science 1997;278:1043-50.

3. Chang WC, Chapkin RS, Lupton JR. Fish oil blocks azoxymethane-induced tumorigenesis by increased cell differentiation and apoptosis rather than decreased cell proliferation. J Nutr 1998;128:491-7.

4. Zoran DL, Turner ND, Taddeo SS, Chapkin RS, Lupton JR. Wheat bran reduces tumor incidence in a rat model of colon cancer independent of effects on distal luminal butyrate concentration. J Nutr 1997; 127:2217-25.

5. Preston-Martin S, Pike MC, Ross RK, Jones PA, Henderson BE. Increased cell division as a cause of human cancer. Cancer Res 1990; 50:7415-21.

6. Hague A, Elder DJE, Hicks DJ, Paraskeva C. Apoptosis in colorectal tumor cells: induction by the short chain fatty acids butyrate, propionate and acetate and the bile salt deoxycholate. Int J Cancer 1995;60:400-6.

7. Chapkin RS, Fan YY, Lupton JR. Effect of diet on colonic-programmed cell death: molecular mechanism of action. Toxicol Lett 2000;112-113:411-4.

8. Boffa LC, Lupton JR, Mariani MR, Ceppi M, Newmark HL, Scalmati et. al. Modulation of colonic epithelial cell proliferation, histone acetylation and luminal short chain fatty acids by variation of dietary fiber (wheat bran) in rats. Cancer Res 1992;52:5906.

9. Hebbes TR, Thorne AW, Robinson CC. A direct link between core histone acetylation and transcriptionally active chromatin. EMBO J 1988;7:1395-402.

10. Merritt AJ, Potten CS, Kemp CJ, Hickman JA, Balmain A, Lane DP, et. al. The role in spontaneous and radiationinduced apoptosis in the gastrointestinal tract of normal and p-53deficient mice. Cancer Res 1994;54(3):614-7.

11. Shaw P, Bovey R, Tardy S, Sahli R, Sordat B, Costa J. Induction of apoptosis by wild type p53 in a human colon tumor derived cell line. Proc Natl Acad Sci USA 1992; 88:4495-9.

12. Princhard DM, Watson AJ. Apoptosis and gastrointestinal pharmacology. Pharmacol Ther 1996; 72(2): 149-69.

13. Lin D, Shields MT, Ullrich SJ, Apella E, Mercer WE. Growth arrest induced by wild typep53 protein blocks cells prior to or near the restriction point in late G1 phase. Proc Natl Acad Sci USA 1992; 89:9210-4.

14. Baker SJ, Fearon ER, Nigro JM, Hamilton SR, Preisinger AC, Jessup JM, et al. Chromosome 17 deletions and p53 gene mutations in colorectal carcinoma. Science 1989; 244:217-21.

15. Kamada S, Shimono A, Shito Y, Tsujimura T, Takahashi $\mathrm{T}$, Noda $\mathrm{T}$, et al. Bcl-2 deficiency in mice leads to pleiotropic abnormalities: accelerated lymphoid cell death in thymus and spleen, polycystic kidney, hair hypopigmentation and distorted small intestine. Cancer Res 1995; 55:354-9. 
16. Ishizuka S, Sonoyoma $\mathrm{K}$, Kasai $\mathrm{T}$. Changes in the number and apoptosis of epithelial cells in the colorectum of wheat bran fed rats soon after administering 1,2-dimethylhydrazine. Biosci Biotech Biochem 1997;61:1337-41.

17. Compher CW, Frankel WL, Tazelaar J, Lawson JA, McKinney S, Segall S, et al. Wheat bran decreases abberant crypt foci, preserves normal proliferation, and increases intraluminal butyrate levels in experimental colon cancer. J Parenter Enteral Nutr 1999;23:269-77.

18. Scheppach W, Bartram HP, Richter F. Role of short chain fatty acids in the prevention of colorectal cancer. Eu J Cancer 1995; 31A:1077-80.

19. Archer SY, Meng S, Shei A, Hodin RA. p $21^{\mathrm{WAF} 1}$ is required for butyrate-mediated growth inhibition of human colon cancer cells. Proc Natl Acad Sci USA 1998;95:6791-6.

20. Siavoshian S, Blottiere HM, Cherbut C, Galmiche JP. Butyrate stimulates cyclin D and p21 and inhibits cyclindependent kinase 2 expression in HT-29 colonic epithelial cells. Biochem Biophys Res Commun 1997;232:169-72.

21. Hague A, Butt AJ, Paraskeva C. The role of butyrate in human colonic epithelial cells: an energy source or inducer of differentiation and apoptosis? Proc Nutr Soc 1996;55(3):937-43.

22. Mahmoud NN, Dannenberg AJ, Bilinski RT, Mestre JR, Chadburn A, Churchill M, et al. Administration of an unconjugated bile acid increases duodenal tumour in murine model of familial adenomatous polyposis. Carcinogenesis 1999;20:299-303.

23. Imray CHE, Radley S, Davis A, Barker G, Hendrickse CW, Donovan IA, et al. Fecal unconjugated bile acids in patients with colorectal cancer or polyps. Gut 1992;33:1239-45.

24. N, Triaspolitica. "Mengenal Penyakit Kanker, Jenis, Gejala, Penyebab Berikut Pengobatan Kanker." Mau Nanya Dong Dok. N.p, 20 June 2017. Web. 28 June 2017. <https://nanyadongdok.blogspot.com/2017/06/ mengenal-penyakit-kangker-jenis-gejala.html>. 